\title{
Creative Problem Solving How Do Undergraduates Perceive the Teaching Practice of Their Professors?
}

\author{
Efrain Duarte Briceño $0^{1, *}$, Maria Teresa Diaz-Mohedo ${ }^{2}$, Jorge Carlos Aguayo Chan ${ }^{1}$ \& Guillermo Baeza Ballote ${ }^{1}$ \\ ${ }^{1}$ Faculty of Psychology, Autonomus University of Yucatan, Mexico \\ ${ }^{2}$ Faculty of Education, University of Granada, Spain \\ *Correspondence: Faculty of Psychology, Autonomus University of Yucatan, Mexico. E-mail: \\ efrain.duarte@correo.uady.mx
}

Received: February 20, 2018

Accepted: March 28, $2018 \quad$ Online Published: April 17, 2018

doi:10.5430/wje.v8n2p152

URL: https://doi.org/10.5430/wje.v8n2p152

\begin{abstract}
The research question was inquiring the undergraduates' perception of their professors' practice regarding whether they make use of the creative problem solving (CPS) as a competence for teaching. The study was performed in a public university located in the urban area of Merida City, Yucatan, Mexico, where a total of 247 undergraduates from the Education, Economy and Psychology schools participated. A Teacher Practice Perception Scale (TPPS) was used to know how undergraduates perceive the professor's practice under the creative problem solving, the facilitating and hindering factors for developing creative solutions, the importance of CPS for the curriculum and proposals to develop CPS in the university instructional practice. The results show that (a) all undergraduates perceive CPS at a high level of importance, (b) Psychology undergraduates perceive a medium-high use of CPS by their professors, and (c) Psychology undergraduates perceive at a higher level the facilitating factors of this process.
\end{abstract}

Keywords: creative problem solving, creative thinking, higher education, teaching practice, undergraduate

\section{Introduction}

The literature review point out that creative thinking is a high level type of thinking which students need for generating, processing and defining ideas, as well as for evaluating their effectiveness and suitability. In general, developing high level thinking skills in the various domains of knowledge usually appears as educational goals in several syllabi; nevertheless, professors regard them as optional objectives once the basic skills are achieved (Andiliou \& Murphy, 2010). According to this, it is important including in the professor's formation the nature of creativity, the creative people profile and the features of an environment which fosters creativity; the later in order to generate favorable attitudes for developing high level thinking skills in the classroom.

Likewise, higher education has focused in creating certain skills and knowledge for satisfying business interests; the later has derived in a competition to reach the highest levels in a hierarchy of educational centers which struggle to draw students to the best rated ones and make the best educational offerings (Galceran, 2010). This phenomenon results in a sort of rating in which certain universities -the ones in the excellence rank- secure more financing and better conditions, whereas those in the lower hierarchies obtain little funding and are usually underrated. As a consequence, the knowledge learned is regarded as merchandise which is offered to the highest bidders, allowing the private businesses to decide how knowledge is crafted.

This phenomenon -which is global- has generated a series of sub-processes which universities have to cope with: quality assessment processes, quality agencies, ranking achievement, educational offering to students from any part of the world, promotion of private higher education centers and creation of "franchises" among the most relevant. Therefore, university studies become a series of cognitive services which privilege the best talents who graduate from higher education centers (Galceran, 2010). These statements generate two conditions:

(1) Articulating the improvement of processes and educational outcomes (higher education institutions seeking educational quality), for which actions to strengthen the academic development have been developing at institutional, local and national level. The main recipients of this development are professors and students; the later should be able to contribute to innovation, be creative and develop abilities for problem solving. 
(2) Possessing features to cope with issues in the field labor (alumni), not only using practical skills and knowledge learned at school.

It is worth mentioning that the cultural context and socio-economic system's interests are factors that affect the social reality where the student must engage these skills (Vela \& Loyo, 2003). Therefore, the competence of creative problem solving (CPS) must be taken into account equally when creating a university syllabus.

According to the aforementioned, the following research question was stated: What are the differences in the students' perception about the teaching practice, factors involved, their importance and proposals regarding CPS within their major? The interest in this question underlies in knowing the professors' practice regarding CPS; which requires knowing whether the student identifies the factors and the degree in which they enable or hinder the use of CPS in the university teaching.

It is then essential to discover what students say about their development inside school, if they can recognize the creative behavior of their professors and their function as promoters of this competence. This is of paramount importance since it is likely that students' expectations and perceptions of their professors have an influence in their learning environment; so knowing them can improve educational instruction, learning process outcomes and the learning environment itself (Stork \& Hartley, 2009).

Similarly, a research about the concept undergraduates have about teaching and learning (Gil Molina, 2014) found that -for the participants- the teacher's role must be oriented towards favoring situations where the student develops analytic, critical thinking and argumentative skills. Therefore, it states the teacher's function as counselor and guide for the student: selecting contents which aid learning as well as texts with relevant information which include activities, allowing the student to find the answer through different procedures.

On the other hand, a study about undergraduate's perspective of university teaching (Villalobos Claveria, Melo Hermosilla \& Perez Villalobos, 2010) did not find differences in male and female perception of the learning and teaching quality. However, regarding teaching in general, female had higher expectations than males.

In theory, it is considered that problem solving is a cyclic process involving a constant moving back and forth around the problem's space, its solution and the action's space (Barbier, Pruneau \& Langis, 2009).

Likewise, problem solution -without considering the creative part- requires of mental operations such as storage, image manipulation and tasks which imply spatial analysis; indeed for learning, humans depend on this type of information.

Some authors (Blosser, 1988; McAllister, 1998; Nickerson, Perkins \& Smith, 1994; Potts, 1994) state that it is important establishing that the relevance of a topic such as "creative problem solution" has decreased these days considering that the validity of knowledge acquired particularly at university, is steadily decreasing; the globalization process confronts human to new situations to solve and that educational policies have privileged process development rather than knowledge acquisition.

All these statements abovementioned lead to the premise that CPS is a competence which can and must be developed as a cross cutting theme in higher education curricula, which transforms the teaching practice (Díaz Mohedo, Vicente Bújez \& Vicente Bújez, 2012; Díaz Nava \& Márquez Guanipa, 2007).

A previous research showed that university professors require and demand training in terms of CPS, and there is no planning to develop this competence; therefore, a challenge for universities is to help them to include activities in their teaching practice to develop this competence in students (Duarte Briceño \& Díaz Mohedo, 2017).

In this sense, teaching practice should be oriented to fostering situations in which students are capable of developing competences for analyzing, arguing and thinking critically. This will require that the professor, as a counselor and guide, have to select contents such as texts with relevant information and activities which allow students to find the solution to the problems posed, in order to foster CPS in the classroom.

Under this perspective, the present research was focused in knowing the student's perception of whether the professor engages in CPS as an educational tool which will enable students to cope with new situations, as it will serve them as a tool to find new ways to solve them. The aim of this study is determining the current situation of CPS as an educational tool development as well as assessing it by the students to identify the improvement areas in the curricula at university level. Furthermore, because we had found statistical differences in order to the type of the major (Duarte Briceño, 1997).

Therefore, we stated the hypothesis that there are statistically significant differences in the undergraduate' perception according to the major they study, regarding the teaching practice, influencing factors, importance and proposals 
related to CPS.

In accordance with the hypothesis mentioned, the main objectives of the present study were: a) Identifying the undergraduate' perception regarding the professor's teaching practice in the classroom based on using CPS, b) knowing which factors affect CPS development of and c) knowing the proposals for nurturing CPS.

\section{Methods}

\subsection{Participants Characteristics}

A total of 247 undergraduates from the following majors participated: 91 from Education, 67 from Economy and 89 from Psychology (table 1). The research was conducted in a public university located in the urban area of Merida, Yucatán, Mexico; which is divided in five campuses: (1) Biological Sciences and Husbandry, (2) Engineering and Exact Sciences, (3) Health Sciences, (4) Social, Economical-Administrative Sciences and Humanities, and (5) Architecture, Art and Design.

The chosen Campus to do the research was Social, Economical-Administrative Sciences and Humanities, comprising the Education, Economy and Psychology schools.

The Anthropological Sciences, Accounting and Administration and Law were excluded from the study, given the number of curricula and/or the number of undergraduates, which lead to differential characteristics in the school dynamics compared to the other schools.

Table 1. Structure of the Sample

\begin{tabular}{|c|c|c|c|c|c|}
\hline Schools & & No. of curricula & $\begin{array}{c}\text { Approximate number of } \\
\text { undergraduates* }\end{array}$ & Sample & $\%$ \\
\hline Education & & 2 & 339 & 91 & 26.8 \\
\hline Economy & & 2 & 426 & 67 & 15.7 \\
\hline Psychology & & 1 & 549 & 89 & 16.2 \\
\hline & Total & 5 & 1,314 & 247 & 18.7 \\
\hline
\end{tabular}

* 2012-2013 school term

\subsection{Measures}

The Teacher Practice Perception Scale (TPPS) was used; which includes 26 statements distributed in four dimensions with five answer choices: 0 which corresponds to Never/no, 1 to A few times, 2 to Half of times, 3 to Many times and 4 to Always. The statements were randomly ordered with the following structure:

Dimension 1. Professor's teaching practice under the creative problem solving, statements:

3. My professor has explained what the CPS process consists of.

9. I like that my professor uses activities to foster CPS during the evaluation.

13. My professor engages CPS in the evaluation.

16. I like that my professor uses activities to foster CPS during class.

18. My professor carries out activities during the semester to develop CPS.

21. My professor fosters in me the value of the CPS process.

22. My professor carries out activities during class to develop CPS.

Dimension 2. Fostering and limiting factors of creative problem solving development, statements:

4. I count with the knowledge to develop a CPS process.

5. My professor is flexible and allows us to use the CPS process.

7. My curriculum requires conditions that allow developing CPS.

8. I am interested in CPS to develop my thinking skills.

17. A limiting factor to CPS development is that I need to know how it works to put it in practice.

19. I consider my professor does not count with knowledge about CPS.

25. A limiting factor to CPS development is that my curriculum requires rigorous knowledge proof. 
Dimension 3. Importance of creative problem solving for the curriculum, statements:

6. Major studies should include activities of CPS because it allows the development of thinking skills.

10. It is necessary that all courses from the curriculum include CPS activities.

11. I value the CPS process and consider it important.

14. I as a student, consider that CPS is an important process in my formation.

15. CPS fosters the development of thinking skills.

23. CPS helps applying knowledge in the labor field.

Dimension 4. Proposals to develop creative problem solving in university teaching, statements:

1. A required strategy for including CPS processes is modifying the curriculum.

2. A required activity to CPS is that my professor must pose problems outside the book.

12. A required activity to CPS is to clearly understand the theory to provide in turn a creative problem solving.

20. A required activity to CPS is that my professor relates the concepts of different subjects.

24. It is necessary to train professors to carry out CPS activities.

26. Professors of different areas must gather and share problems to solve creatively.

\section{Results}

An item Discriminant Analysis was conducted using the $t$ test for two independent samples, which proved that all items were effective to separate undergraduates who vary in their degree of knowledge of the material tested. Based on the obtained data, an internal consistency analysis was performed using the Cronbach alpha, which produced a coefficient of .836, which provides a high reliability to the instrument (Aiken, 1994; Cohen \& Swerdlik, 2006). All this data commended the use of the survey. The language of the instruction and the survey was Spanish.

Similarly, a general descriptive analysis of the three schools studied (Education, Economy and Psychology) was performed, however, in the Fostering and limiting factors of CPS development dimension, these factors were divide since some had a positive and others a negative value; also, in the Proposals to develop CPS in university teaching dimension, the analysis was done for each of the options included (table 2). As it can be observed, the general perception of all undergraduates are above the preset mean value of the scale $\left(M_{t}=2\right)$.

Table 2. General Indicators for the Teacher Practice Perception Scale

\begin{tabular}{|c|c|c|c|c|c|}
\hline \multicolumn{2}{|c|}{ Dimension } & Minimum & Maximum & $M^{*}$ & $S D^{*}$ \\
\hline \multicolumn{2}{|c|}{ Teacher performance } & .14 & 4.00 & 2.66 & .738 \\
\hline \multirow{2}{*}{ Factors } & Fostering & .67 & 4.00 & 3.01 & .658 \\
\hline & Limiting & .00 & 3.75 & 2.16 & .653 \\
\hline \multicolumn{2}{|c|}{ Importance of creative problem solving } & 1.17 & 4.00 & 3.33 & .528 \\
\hline \multicolumn{2}{|c|}{ Curriculum modification } & .00 & 4.00 & 2.02 & 1.00 \\
\hline \multirow{5}{*}{ Proposals } & Posing problems outside the book & .00 & 4.00 & 2.82 & .993 \\
\hline & $\begin{array}{l}\text { Clearly understanding the theory to } \\
\text { provide a creative solution to a problem }\end{array}$ & 1.00 & 4.00 & 3.17 & .867 \\
\hline & Relating the concepts of different subjects & .00 & 4.00 & 2.71 & .939 \\
\hline & $\begin{array}{l}\text { Training professors to carry out CPS } \\
\text { activities }\end{array}$ & .00 & 4.00 & 3.07 & .997 \\
\hline & $\begin{array}{l}\text { Conduct meetings among professors from } \\
\text { different areas to solve problems creatively }\end{array}$ & .00 & 4.00 & 3.15 & .905 \\
\hline
\end{tabular}

* $\mathrm{M}=$ Mean, $\mathrm{SD}=$ Standard deviation (APA, 2010)

In order to establishing significant differences among participants of each school included, a one factor analysis of variance was conducted, obtaining differences in the following dimensions: Professor's teaching practice under the CPS, Fostering and limiting factors of CPS development and Proposals to develop CPS in university teaching; the last one in relation to the Curriculum modification and Training professors to carry out CPS activities aspects (table $3)$. 
Table 3. Differences in the Teaching Practice Perception by School

\begin{tabular}{|c|c|c|c|c|c|c|}
\hline \multirow{2}{*}{\multicolumn{2}{|c|}{ Dimension }} & \multicolumn{3}{|c|}{$M^{*}$ by school } & \multirow[t]{2}{*}{$F$} & \multirow[t]{2}{*}{$p$} \\
\hline & & Econ. & Edu. & Psy. & & \\
\hline \multicolumn{2}{|c|}{ Teacher performance } & 2.48 & 2.58 & 2.87 & 6.29 & .002 \\
\hline \multirow{2}{*}{ Factors } & Fostering & 2.80 & 2.94 & 3.24 & 10.03 & .000 \\
\hline & Limiting & 2.44 & 2.26 & 1.85 & 19.78 & .000 \\
\hline \multicolumn{2}{|c|}{ Importance of creative problem solving } & 3.24 & 3.32 & 3.40 & 1.84 & .160 \\
\hline \multirow{6}{*}{ Proposals } & Curriculum modification & 2.36 & 2.08 & 1.71 & 8.73 & .000 \\
\hline & Posing problems outside the book & 2.75 & 2.80 & 2.89 & .403 & .669 \\
\hline & $\begin{array}{l}\text { Clearly understanding the theory to provide a } \\
\text { creative solution to a problem }\end{array}$ & 3.24 & 3.03 & 3.26 & 1.82 & .164 \\
\hline & Relating the concepts of different subjects & 2.82 & 2.80 & 2.53 & 2.60 & .076 \\
\hline & Training professors to carry out CPS activities & 3.46 & 3.18 & 2.67 & 14.06 & .000 \\
\hline & $\begin{array}{l}\text { Conduct meetings among professors from } \\
\text { different areas to solve problems creatively }\end{array}$ & 3.19 & 3.25 & 3.01 & 1.72 & .181 \\
\hline
\end{tabular}

* M = Mean (APA, 2010)

In relation to the professor's teaching practice, participants from Psychology perceived them with a higher level $(M=$ 2.87) in the CPS competence, which included carrying out this type of activities during class and evaluation, as well as explaining what the process consisted of and appreciating it. Despite this significant difference, the all participant's mean is within a medium-high level $(M=2.66)$.

Regarding the Fostering and Limiting CPS development factors, Psychology undergraduates perceived more fostering factors $(M=3.24)$, such as counting with the knowledge for developing the process, interest in developing students' thinking skills and flexibility to allow these type of activities; on the other hand, Economy students perceived more limiting factors $(M=2.44)$, such as considering that professors have no knowledge about the process, the curriculum requires certain conditions to allow CPS as it states rigorous knowledge proof and participants ignore how the process works in order to put it in practice.

In the case of the Importance of CPS for the curriculum, there were no significant differences, but rather than representing a negative trait, it is seen as something favorable, due to all participants agreeing in a high level of importance (Economy, $M=3.24$; Education, $M=3.32$; Psychology, $M=3.40$ ). This result indicates all participants consider that CPS fosters thinking skills development, aids in applying knowledge in the labor field and is an important process in the academic formation. Consequently, activities of this type should be included in subjects from all curricula.

Finally, regarding the Proposals to develop CPS in university teaching, and considering the significant differences found, Economy undergraduates were the most who considered the curriculum must be modified to include these type of activities $(M=2.36)$, and that professors must be trained to carry out such activities $(M=3.46)$. In general descriptive terms, besides the two aforementioned proposals, participants placed in a high level, those referring to clearly understand the theory to give a creative solution to a problem $(M=3.17)$ and sustaining meetings among professors to share problems to solve creatively $(M=3.15)$.

\section{Discussion}

The research question was to know the undergraduates' perception in relation to the professor's teaching practice which uses CPS. Firstly, all participants gave a high level of importance to CPS. As a result, it can be inferred that participants are aware of the skills they can develop with the use of CPS. As Gil Molina (2014) mentions, the teacher's role must be oriented to foster CPS in the student to develop analyzing, arguing and thinking critically skills.

On the other hand, Psychology school undergraduates perceived their professors with a higher level of CPS use, which includes conducting these types of activities during class and evaluation. As mentioned by Smith (2008), CPS is produced and depends on implicit and explicit cognitive processes, where their interaction can lead to precise results but also to cognitive illusions, particularly biased by the role of previous knowledge in the thinking process. This could stem from the fact Psychology undergraduates are more immersed in creativity topics, which could generate a bias or tendency to perceive this quality in their professors. The later could also similarly explain why 
Psychology undergraduates perceive more fostering factors.

On the contrary, Economy undergraduates perceive more limiting factors as opposed to the other participants, consider the curriculum must be modified to include activities related to CPS, and professors must be trained to carry out these activities.

To produce such changes, all curricular levels and activities must be embraced. From the premise that the purpose of school is to nurture talent in students, it is necessary that students as well as professors acquire skills to develop a problem solution and creativity focused personality as mentioned by Marina and Marina (2013).

Taking the latter point first, Economy undergraduates consider the curriculum must be modified to include this type of activities and that professors need to be enabled to conduct them. Therefore, it is possible that these activities are not very present in the curriculum; so if a change is to occur, such curriculum will need to be adjusted. It will also be required that professors are enabled to perform activities that Foster CPS.

Based on what has been discussed throughout the present research, we state the following conclusions:

- Despite international policies on higher education establish creativity and problem solving -which are integrated as one in the present study- as a competence to develop in students, it is not being planned and systematically implemented in the studied university, at least not in the Social Sciences Campus.

- Including professors from one only area of knowledge -social sciences and humanities- out of the five which comprise the university setting, provided results which apply for a particular situation.

- University professors require formation regarding the CPS competence to incorporate it in their daily practice with the aim of developing this competence in undergraduates.

- Finally, all the information gathered in the present work highlights the importance of CPS in today undergraduates' formation.

\section{References}

Aiken, L. R. (1994). Psychological testing and assessment (8th Ed.). Unitet States of America: Ally and Bacon.

Andiliou, A., \& Murphy, P. K. (2010). Examining variations among researchers' and teachers' conceptualizations of creativity: A review and synthesis of contemporary research. Educational Research Review, 5, 201-219. https://doi.org/10.1016/j.edurev.2010.07.003

Barbier, P. Y., Pruneau, D., \& Langis, M. (2009). Unfolding bein-with-environment through creative problem solving in environmental education. The International Journal of Learning, 16(2), 499-510. https://doi.org/10.18848/1447-9494/CGP/v16i02/46142

Blosser, P. E. (1988). Teaching Problem Solving-Secondary School Science. ERIC/ SMEAC Science Education Digest No. 2, pp. 1-6. ERIC Identifier: ED309049. Recuperado de http://www.eric.ed.gov.

Cohen, R. J., \& Swerdlik, M. E. (2006). Pruebas y evaluación psicológica. Introducción a las pruebas y a la medición. México: McGraw-Hill Interamericana.

Díaz Mohedo, M. T., Vicente Bújez, A., \& Vicente Bújez, M. R. (2012). Nuevas formas de aprender en la Universidad que mira al futuro. En J. I Alonso, A. Escarbajal y R. Nortes (Eds.), Experiencias de innovación en Educación Infantil y Educación Primaria. (130-134). Murcia: Ediciones de la Universidad de Murcia. Recuperado de http://hdl.handle.net/10481/27627

Díaz Nava, J., \& Márquez Guanipa, J. (2007). Estimación del potencial en la implementación de ejes transversales en instituciones de educación superior. SAPIENS, Revista Universitaria de Investigación, Año 8, 1, 205-224, Universidad Pedagógica Experimental Libertador, Caracas, Venezuela.

Duarte Briceño, E., \& Díaz Mohedo, M. (2017). Solución creativa de problemas como competencia docente, el discurso de los profesores. Journal for Educators, Teachers and Trainers, 8(1), 226-238.

Duarte Briceño, E. (1997). Niveles diferenciales de creatividad gráfica y su relación con el tipo de personalidad en estudiantes universitarios. (Tesis de Maestría inédita). Universidad Autónoma de Yucatán, Mérida, México.

Galcerán, M. (2010). La educación universitaria en el centro del conflicto. En Edu-Factory y Universidad Nómada (comps.). La universidad en conflicto. Capturas y fugas en el mercado global del saber (pp. 13-39). Madrid: Traficantes de sueños. 
Gil Molina, P. (2014). Concepciones sobre la enseñanza y el aprendizaje del alumnado del Máster de Formación del Profesorado de Educación Secundaria de la Universidad del País Vasco. Magister, 26(2), 67-74. https://doi.org/10.1016/S0212-6796(14)70020-9

Marina, J. A., \& Marina, E. (2013). El aprendizaje de la creatividad. Biblioteca UP, Lo que los padres y docentes deben saber. España: Ariel.

McAllister, H. C. (1998). Problem Solving and Learning. University of Hawaii at Manoa. Retrieved from http://www.hawaii.edu/suremath/learn1.html

Nickerson, R. S., Perkins, D. N., \& Smith, E. E. (1994). Enseñar a pensar. Aspectos de la aptitud intelectual (3rd ed.). España: Paidós/M.E.C.

Potts, B. (1994). Strategies for Teaching Critical Thinking. ERIC/AE Digest. ERIC Identifier: ED385606, pp. 1-5. Retrieved from http://www.eric.ed.gov

Smith, S. M. (2008). Invisible assumptions and the unintentional use of Knowledge and experiences in creative cognition. Lewis \& Clark Law Review, 12(2), 509-525.

Stork, E., \& Hartley, N. T. (2009). Classroom Incivilities: Students' Perceptions about Professors' Behaviors. Contemporary Issues in Education Research, 2(4), 13-24. http://dx.doi.org/10.19030/cier.v2i4.1066

Vela S., R., \& Loyo H., L. (2003). Las políticas públicas en el futuro de la educación en el nuevo contexto internacional. México: Asociación de Educadores de Latinoamérica y el Caribe, Instituto Nacional de Administración Pública, Instituto de Administración Pública de Yucatán y Red Nacional de Instituciones Estatales de Administración Pública.

Villalobos Clavería, A., Melo Hermosilla, Y., \& Pérez Villalobos, C. (2010). Percepción y expectativas de los alumnos universitarios frente al profesor no pedagogo. Estudios Pedagógicos, 36(2), 241-249. https://doi.org/10.4067/S0718-07052010000200014 